\title{
An Irish sociology professor writes a student reference, May 1958
}

\author{
PETER MURRAY
}

Maynooth University

\begin{abstract}
From the Dublin Diocesan Archives a May 1958 letter from Maynooth Sociology Professor Jeremiah Newman to the Director of the Dublin Institute of Catholic Sociology appraises the contribution that a group of students about to be ordained for the Dublin archdiocese might best make to the Institute's work. A Cold War context of politico-ideological struggle links this peculiarly Irish epistle with an international literature concerning letters of recommendation and reports to police agencies about practitioners of sociology.
\end{abstract}

Keywords: archives, Catholic Church, Catholic Sociology, adult education, Cold War

At the end of the 1960s a radical critical of the American Sociological Association (ASA) establishment charged that 'in addition to the general dissemination of propaganda, professional sociology has the major specific functions of aiding industrial, civil and military authorities in the solution of manpower control problems of a limited order and of preparing university candidates for careers in the official bureaucracies' (Nicolaus 1972: 46). Letters of recommendation form part of this career preparation process. A Marxist of the New Left variety, Michael Burawoy (2005) has published a remarkably negative document of this type that he was unwise enough to solicit during this turbulent period of US academic and political history from Edward Shils, a 1930s leftist who had moved steadily to the right in the post-war decades (Independent 1995).

The various authorities that US professional sociology stood indicted of aiding were not always fully appreciative of the help they were purported to receive from this quarter. Talcott Parsons, the epitome of ASA conservatism for a critic like Nicolaus, had himself earlier endured a Federal Bureau of Investigation (FBI) grilling prompted by accusations of communist sympathies from people whose names have been redacted in documents released under US Freedom of Information legislation but who were almost certainly academic 
colleagues of his. Alongside unabashed radicals like C. Wright Mills, other US sociologists whose left-wing leanings were scarcely more pronounced than those of Parsons attracted similar FBI attention (Keen 1999). Until the collapse of the Soviet Union and its system of satellite states, sociologists in much of central and eastern Europe worked under constant surveillance and risked sanctions for deviating from Marxist-Leninist orthodoxy (Keen and Mucha 1994).

Operating under the shadow of an institution insistent on obedience and intolerant of dissent was also a feature of Irish sociology's historical environment. Prior to the Second World War the Catholic Church was a monopoly provider of sociological education with no rivals to fend off (Conway 2011). Catholic sociology was a subject taught mainly in seminaries and in the diocesan colleges with the jewel in its crown being the Chair in Catholic Sociology and Catholic Action that the Knights of Saint Columbanus had endowed in the national seminary, St Patrick's College, Maynooth. Vatican oversight of the Irish church included a June 1939 request for information from the Irish hierarchy 'in order that a start may be made towards ensuring some practical provision for a deeper study of Catholic sociology in the Seminaries of Ireland' (Robinson 1939). In response came an assurance that 'everything necessary is now being done in this very important branch of priestly education' and that 'these measures are adequate to meet any possible danger to religion ... there is very little danger of Socialism or Communism obtaining a footing amongst [the Irish people]' (Irish Hierarchy Sub-Committee 1939).

The wartime/'Emergency' years were to lead to a reappraisal of the extent of this danger for domestic as well as international reasons. Then a surge in popular support for the Labour Party preceded a 1944 split in which communist penetration of the party was raised as a central issue. In the following year the trade union movement also split. When one wing of the divided union movement then founded a People's College which modelled its adult education approach on the British Workers' Educational Association, a strong Catholic counter-movement quickly developed. This utilised the existing institutional base of the National University of Ireland (NUI) with extra-mural programmes being pioneered by University College Cork (UCC) President Alfred O'Rahilly and then introduced by University College Dublin (UCD) and University College Galway (UCG). In Dublin two new adult education institutions also emerged - a Catholic Workers College (CWC) run by the Jesuits and the Dublin Institute of Catholic Sociology (DICS) founded by Archbishop McQuaid.

The adult education movement expanded participation in the study of Catholic sociology beyond the ranks of seminarians and potential seminarians. With the local threat from communism or socialism so weak, it quickly widened its focus to include social strata other than its initial trade unionist target group such as farmers, farmers' wives and white-collar workers. In Cork and neighbouring counties O'Rahilly forged effective alliances with Vocational Education Committees (VECs) and insisted that sociology be taught as part 
of every course. Around Dublin poor relations between UCD and the VECs combined with the independent archdiocesan initiative of Archbishop McQuaid to produce much more fragmented provision to which sociology was less consistently central.

In the UCC system while other teachers were appointed in the usual way by the VEC 'it has been agreed that the teacher of Sociology should be appointed by the Catholic Bishop of the diocese' (O'Rahilly 1952). In centres outside the city where UCD Board of Extra-Mural Studies courses were run 'usually the rural lecturers are drawn from the local Technical and Secondary schools with political theory and social ethics taught by the local curate, or some priest' (O'Doherty 1954). DICS started life in the early 1950s as the Dublin Diocesan Study Centre where meeting facilities were provided for a number of existing, mainly workplace-based study groups each of which had a priest as director. The demand for priest-teachers of sociology courses from the adult education sector provides the context for the peculiarly Irish clerical letter of academic recommendation from the St Patrick's College, Maynooth Professor of Sociology to the Director of the DICS reproduced in Box 1. The subject is the contribution that six Dublin diocesan students on the point of completing their studies in Maynooth can make to the work of the Institute after their ordination as priests.

\section{Box 1}

Copy of letter dated 13 May 1958 from Jeremiah Newman, Professor of Sociology, St Patrick's College, Maynooth to Fr. Thomas Fehilly, Director, Dublin Institute of Catholic Sociology, Dublin Diocesan Archives McQuaid Papers AB/8/B/XXXV (10-15) Adult Education Dublin Institute of Catholic Sociology folder 1958. Because a number of the six students referred to in the letter are still living, it is necessary to redact their names in order to comply with the requirements of data protection legislation. I am indebted to Archbishop Diarmuid Martin for permission to reproduce the letter and to Noelle Dowling, Dublin Diocesan Archivist, for her advice and assistance.

Dear Tom,

Long time no see, or hear. I do not know to what extent you are making use of Maynooth men in connection with the Institute. However, in accordance with my custom I am writing to let you know the form, from the point of view of Sociology, of the men going out this year. I had them up to the night before last. $\mathrm{U}$ should be useful. He is very zealous and though not brilliant is very sound. So too is $\mathrm{V}$ and $\mathrm{W}$.

$\mathrm{X}$ is a sound man also, though his line may not exactly be lecturing. You would find him invaluable in connection with bringing out the Bulletin and work like 
that. The same is true of $\mathrm{Y}$ who has great gifts in the line of organisation. I think that he would like to be asked to help you in some capacity.

$\mathrm{Z}$ is a deep and sound man, not brilliant but reliable. I suspect that there is a lot in him and that if asked to do a job, he would do so efficiently. In general I find this bunch of Dublin lads this year a very fine one and of great potential use.

Hoping to see you soon,

All best wish,

Jerry Newman

In 1958 Jeremiah Newman's former students were unlikely to be left uninvited to participate such was the extent to which the DICS activities were growing under Fr. Fehilly's energetic direction. As external and rural centres were added to a growing central city base, more priests from religious orders as well as the diocesan clergy were recruited and lay people began to make up a significant minority of DICS teachers. The Archbishop himself acknowledged the close of an exclusively clerical era when he responded in October 1960 to a memorandum from Fr. Fehilly making the case for more resources to be provided to support the Institute's work - 'it reads like a thesis on an ideal Institute ... while it may be pleasant to extend the Institute, imperially, the Archbishop has to find the staff. I am gravely straitened for want of priests' (McQuaid 1960).

Dated 13 May 1958 Jeremiah Newman's letter is written during a year of significant innovation within Irish sociology. First, funding was secured and preparations got under way for the Limerick Rural Survey (Murray and Feeney 2011). Second, Newman undertook a tour of the USA to secure expert advice for the Limerick project and to seek resources for a scheme of scholarships that would enable Irish students to study sociology in US universities (Murray 2012) Third, there was - in response to European prompting - the first move to create an infrastructure for social science research in Ireland with the setting up of the National Joint Committee for the Human Sciences and Their Application to Industry (Murray 2009: 164-86). Irish sociology was still clerical and Catholic but it was rapidly moving beyond the fairly sterile exposition of ethical principles that had characterised its early decades to take an empirical turn (Conway 2011). At Maynooth, Newman was in the vanguard of this movement: in Dublin it proceeded mainly at UCD under the patronage of an Archbishop 'whose deep interest in social questions led him to pioneer the contemporary approach by sending priests of his own diocese for post-graduate training in the social sciences and by incessantly urging the pastoral importance of such training' (Ward 1964: 26).

1958 is also usually presented as a watershed year for the southern Irish state. Then the publication of Economic Development - the 'Grey book' written by Department of Finance Secretary T.K. Whitaker and his associates - charted a new policy course away from inward-looking cultural and economic protectionism 
and towards an opening up to the wider world of European integration and transnational capital. Civil service planners pursuing this strategy were soon to perceive empirical sociology as a useful resource for their project. In the course of the 1960s the technocrats would begin to take over direction of the discipline by marginalising Catholic Church actors within the field of empirical social research and by reconstructing education in line with a 'mercantilist' rather than a 'theocentric' paradigm (O'Sullivan 2005). As they did so, the form in which the discipline's letters of recommendation were written was to be one of its many altered features.

\section{Notes}

1 Beyond the seminaries University College Cork established a lectureship in sociology in 1937. When the college found that it did not have the funds to pay a new appointee, Alfred O'Rahilly - then UCC's Registrar - took on the additional role of unpaid sociology lecturer for nearly a decade until Fr. Jerome O'Leary filled the post.

\section{References}

Burowoy, M. 2005. 'Antinomian Marxist', pp. 48-71 in A. Sica and S. Turner (eds), The Disobedient Generation: Social Theorists in the Sixties. Chicago: University of Chicago Press.

Conway, B. 2011. 'Catholic sociology in Ireland in comparative perspective', American Sociologist 42(1): 34-55.

Independent 1995. Obituaries: Professor Edward Shils, 27 January.

Irish Hierarchy Sub-Committee 1939. Report on Education of Clergy in Social Science. Archbishop Byrne Papers, Box Irish Bishops, Folder Province of Tuam, sub-folder Clonfert. Dublin Diocesan Archives, Dublin.

Keen, M.F. 1999. Stalking the Sociological Imagination: J Edgar Hoover's FBI Surveillance of American Sociology. Westport, CT: Greenwood Press.

Keen, M.F. and J. Mucha 1994. Eastern Europe in Transformation: the Impact on Sociology. Westport, CT: Greenwood Press.

McQuaid, J.C. 1960. Letter to Fr. T. Fehilly, 9 October, Archbishop McQuaid Papers, $\mathrm{AB} / 8 / \mathrm{B} / \mathrm{XXXV}$ (10-15) Adult Education Dublin Institute of Catholic Sociology, folder 1960 - 162, Dublin Diocesan Archives, Dublin.

Murray, P. 2009. Facilitating the Future? US Aid, European Integration and Irish Industrial Viability, 1948-73. Dublin: UCD Press.

Murray, P. 2012. "Much leeway needs to be made up in our equipment": Muintir na Tire and US scholarships for Irish sociology students, 1958-59', Irish Journal of Sociology 20(1): 65-83.

Murray, P. and M. Feeney 2011. 'The market for sociological ideas in early 1960s Ireland: civil service departments and the Limerick Rural Survey, 1961-64', Administration 59(1): 111-31.

Nicolaus, M. 1972. 'The professional organization of sociology: a view from below', pp. 45-60 in R. Blackburn (ed.), Ideology and Social Science: Readings in Critical Social Theory. London: Fontana. 
O’Doherty, E.F. 1954. Letter to 'Dear Chris', 11 November, Archbishop McQuaid Papers AB/8/B/XXXV (10-15), Adult Education Dublin Institute of Catholic Sociology Folder 1953-55, Dublin Diocesan Archives, Dublin.

O'Rahilly, A. 1952. University College Cork Memo from the President Adult Education, 1 February, Archbishop McQuaid Papers AB/8/B/XXXV (10-15), Adult Education Dublin Institute of Catholic Sociology, Folder 1953-55, Dublin Diocesan Archives, Dublin.

O'Sullivan, D. 2005. Cultural Politics and Irish Education Since the 1950s: Policy, Paradigms and Power. Dublin: Institute of Public Administration.

Robinson, P. 1939. Letter to Cardinal MacRory, 10 June, Cardinal MacRory Papers, ARCH 11/1/4 Apostolic Nunciature, Cardinal Tomás Ó Fiach Memorial Library and Archive, Armagh.

Ward, C. 1964. 'Socio-religious research in Ireland', Social Compass 11(3): 25-9. 